\title{
Renal Uptake of 99mTc-Dimercaptosuccinic Acid Is Dependent on Normal Proximal Tubule Receptor-Mediated Endocytosis
}

\author{
Kathrin Weyer ${ }^{1}$, Rikke Nielsen ${ }^{1}$, Steen V. Petersen ${ }^{1}$, Erik I. Christensen ${ }^{1}$, Michael Rehling ${ }^{2}$, and Henrik Birn ${ }^{1,3}$ \\ ${ }^{I}$ Department of Biomedicine, Aarhus University, Aarhus, Denmark; ${ }^{2}$ Department of Clinical Physiology and Nuclear Medicine, \\ Aarhus University Hospital, Aarhus, Denmark; and ${ }^{3}$ Department of Nephrology, Aarhus University Hospital, Aarhus, Denmark
}

\begin{abstract}
99mTc-labeled dimercaptosuccinic acid (99mTc-DMSA) accumulates in the kidney cortex and is widely used for imaging of the renal parenchyma. Despite its extensive clinical use, the mechanism for renal targeting of the tracer is unresolved. Megalin and cubilin are cooperating receptors essential to the proximal tubule endocytic uptake of proteins from the glomerular ultrafiltrate. We have used megalin/cubilin-deficient mice produced by gene knockout to determine whether receptor-mediated endocytosis is responsible for the renal uptake of $99 \mathrm{mTc}-\mathrm{DMSA}$. Methods: Control or megalin/cubilin-deficient mice were injected intravenously with $0.5 \mathrm{MBq}$ of ${ }^{99 \mathrm{mTC}} \mathrm{Tc}$-DMSA or ${ }^{99 \mathrm{mTc}} \mathrm{Tc}$ mercaptoacetyltriglycine (MAG3). Whole-body scintigrams and the activity in plasma, urine, and the kidneys were examined $6 \mathrm{~h}$ after injection. The size and identity of $99 \mathrm{mTc}$-DMSA-bound proteins in urine were analyzed by fractionation by centrifugation and separation by sodium dodecyl sulfate polyacrylamide gel electrophoresis, followed by autoradiography and mass spectrometry. Results: No renal accumulation of ${ }^{99 m}$ Tc-DMSA was identified in scintigrams of megalin/cubilin-deficient mice. The renal accumulated activity of the tracer was reduced to $11.4 \%$ $( \pm 2.5 \%, n=7)$ of the normal uptake in control mice, correlating with a reduction in renal megalin/cubilin expression in knockout mice to about $10 \%$ of normal. The reduced renal uptake in megalin/cubilin-deficient mice was accompanied by an increase in the urinary excretion of 99mTc-DMSA. Size separation of the urine by ultracentrifugation and sodium dodecyl sulfate polyacrylamide gel electrophoresis demonstrated that in megalin/cubilin-deficient mice an increased amount of 99mTc-DMSA was excreted in an approximately $27-\mathrm{kDa}$ form, which by mass spectrometry was identified as the plasma protein $\alpha 1$-microglobulin, an established megalin/cubilin ligand. Conclusion: $99 \mathrm{mTc}-\mathrm{DMSA}$ is filtered bound to $\alpha 1$-microglobulin and accumulates in the kidneys by megalin/cubilin-mediated endocytosis of the $99 \mathrm{~m}$ Tc-DMSA protein complex. Renal accumulation of 99mTc-DMSA is thus critically dependent on megalin/cubilin receptor function and therefore is a marker of proximal tubule endocytic activity.
\end{abstract}

\footnotetext{
Received Jun. 29, 2012; revision accepted Aug. 15, 2012.

For correspondence or reprints contact: Kathrin Weyer, Department of Biomedicine, Aarhus University, Wilhelm Meyers Allé 3, Building 1234, DK8000, Aarhus C, Denmark.

E-mail: kwey@ana.au.dk

Published online Dec. 11, 2012.

COPYRIGHT @ 2013 by the Society of Nuclear Medicine and Molecular Imaging, Inc.
}

Key Words: renogram; megalin; cubilin; kidney

J Nucl Med 2013; 54:159-165

DOI: 10.2967/jnumed.112.110528

\section{D}

imercaptosuccinic acid (DMSA) labeled with ${ }^{99} \mathrm{~m} \mathrm{Tc}$ is a major renal cortical imaging agent used in the diagnosis of renal parenchymal disorders (1). ${ }^{99 \mathrm{~m}} \mathrm{Tc}-\mathrm{DMSA}$ is highly accumulated in the kidney cortex (2), but the mechanism for the renal targeting of the tracer has not been established. Two main routes of ${ }^{99 \mathrm{~m}}$ Tc-DMSA tubular uptake have been proposed: by basolateral uptake from plasma by peritubular extraction and by tubular reabsorption from the glomerular ultrafiltrate. However, the significance of both routes is debated (3-12). The sodium-dependent dicarboxylate transporter NaDC-3 has been implicated in the basolateral uptake of $99 \mathrm{~m}$ Tc-DMSA from peritubular capillaries into proximal tubule cells (13). The mechanism by which ${ }^{99 m}$ Tc-DMSA may be reabsorbed from the glomerular ultrafiltrate is unknown; however, studies have indicated that this route may contribute substantially to the renal uptake of the tracer $(4,5,14)$. The potential importance of this pathway is further stressed by recent observations of a decreased renal uptake of ${ }^{99 m}$ Tc-DMSA in patients with proximal tubular endocytic dysfunctions, such as Dent's disease, Lowes syndrome, and Fanconi syndrome $(10,15,16)$.

The cooperating receptors megalin and cubilin are responsible for the endocytic uptake of proteins from the glomerular ultrafiltrate in the proximal tubule $(17,18)$. Megalin, a member of the low-density lipoprotein receptor family, is a $600-\mathrm{kDa}$ transmembrane glycoprotein with more than 50 known ligands, including a variety of plasma proteins. Megalin functions in a complex with the $460-\mathrm{kDa}$ extracellular protein cubilin. Cubilin also binds several plasma proteins, including albumin, but depends on megalin for the endocytosis of cubilin-ligand complexes $(19,20)$. Accordingly, megalin/cubilin-deficient mice excrete several low-molecular-weight proteins in the urine, including $\beta 2$-microglobulin, $\alpha 1$-microglobulin, and retinol-binding protein, characteristic of tubular proteinuria caused by proximal tubule endocytic dysfunction (20-22). Megalin/ cubilin dysfunction has been implicated in the pathogenesis 
of various renal diseases, such as the early stages of diabetic and hypertensive nephropathy, and other conditions of proteinuria (23). However, there are currently no assays for direct quantitation and imaging of proximal tubule receptor-mediated endocytic function.

Our aim was to investigate if the megalin/cubilin receptor complex is important for renal ${ }^{99 m}$ Tc-DMSA accumulation. Using conditional megalin/cubilin-deficient mice and examining the renal uptake and urinary excretion of tracer, we identified a crucial role of the megalin/cubilin receptors for the accumulation of ${ }^{99 \mathrm{~m}} \mathrm{Tc}-\mathrm{DMSA}$ and suggest a mechanism of uptake involving glomerular filtration and proximal tubule endocytosis of protein-bound tracer.

\section{MATERIALS AND METHODS}

\section{Animals}

Animal breeding and experiments were performed in a certified animal facility according to provisions approved by the Danish Animal Experiments Inspectorate. The conditional megalin/cubilindeficient mice used were $\mathrm{Meg}^{\mathrm{lox} / \mathrm{lox}}, \mathrm{Cubn}^{\mathrm{lox} / \mathrm{lox}}$,Wnt4-Cre+ mice, where the Cre-recombinase gene is driven by the Wnt4 promoter (22). Genotyping was made on tail DNA by polymerase chain reaction as described before (20). Cre-negative littermates were used as controls. The mice were on a mixed C57BL/6-129/Svj background and 8-12 wk old at the time of use. The body weights of megalin/cubilin-deficient and control mice were $27.4 \pm 4.8 \mathrm{~g}$ and $26.9 \pm 1.8 \mathrm{~g}(P=0.39)$, respectively. Megalin/cubilin-deficient mice displayed left and right kidney weights of $91.8 \pm 31.5$ and $112.7 \pm 42.8 \mathrm{mg}$, respectively, which was not significantly different from the kidney weights of controls of $79.3 \pm 20.0$ and $102.2 \pm$ $20.4 \mathrm{mg}(P=0.20$ and $P=0.28)$, respectively.

\section{Radiotracers}

DMSA was prepared using a commercially available kit, Renosis DMSA (RH-Isotopagenturet). Mercaptoacetyltriglycine (MAG3) was prepared using a commercially available kit, MAG3 Technescan (DRN 4334; RH-Isotopagenturet). The tracers were labeled according to the manufacturer's instructions by adding $1,000 \mathrm{MBq}$ of freshly eluted ${ }^{99 \mathrm{~m}} \mathrm{TcO}^{-}$(pertechnetate) to a final concentration of $200 \mathrm{MBq}$ per $\mathrm{mL}$. Radiochemical purity was above $95 \%$.

\section{9mTc-DMSA and 99mTc-MAG3 Uptake Studies in Mice}

Megalin-/cubilin-deficient or control mice were anesthetized with isoflurane for a few minutes for the intravenous injection in the femoral vein of $0.5 \mathrm{MBq}$ of ${ }^{99 \mathrm{~m}} \mathrm{Tc}-\mathrm{DMSA}$ or ${ }^{99 \mathrm{~m}} \mathrm{Tc}-\mathrm{MAG} 3$ in a total volume of $0.1 \mathrm{~mL}$ of saline. The mice were placed in metabolic cages for $6 \mathrm{~h}$ for urine collection. At the end of the 6-h urine collection, the mice injected with ${ }^{99 \mathrm{~m}} \mathrm{Tc}-\mathrm{DMSA}(n=7$ in each group) were anesthetized, and the remaining urine in the bladder and the kidneys was collected. A blood sample was collected into a syringe containing heparin. Blood and urine samples were centrifuged for $10 \mathrm{~min}$ at $1,600 \mathrm{~g}$. Specimens $(50 \mu \mathrm{L})$ of plasma and urine, and the whole kidneys, were counted using a $\gamma$-counter (Packard Biosciences). Renal imaging was performed by placing megalin/cubilin-deficient mice injected with ${ }^{99 \mathrm{~m}} \mathrm{Tc}$ DMSA or control mice ( $n=3$ in each group) directly on the detector of a $\gamma$-camera (BrightView, Philips Healthcare) with a low-energy high-resolution collimator. Planar images were acquired over $10 \mathrm{~min}$ in a $256 \times 256$ matrix.

\section{Size Fractionation of Urine}

Urine from megalin/cubilin-deficient mice injected with ${ }^{99 \mathrm{~m}} \mathrm{Tc}-$ DMSA or control mice ( $n=3$ in each group) was pooled, and $800 \mu \mathrm{L}$ were applied on centrifuge filters (Amicon; Millipore) with a molecular weight cutoff at 100, 30, 10, 3, and less than $3 \mathrm{kDa}$, and separated by centrifugation at $4,000 \mathrm{~g}$. Samples were counted using a $\gamma$-counter before and after the fractionation.

\section{Sodium Dodecyl Sulfate Polyacrylamide Gel Electrophoresis (SDS-PAGE) and Protein Visualization}

Urine samples $(15 \mu \mathrm{L})$ collected from megalin/cubilin-deficient mice injected with ${ }^{99 m}$ Tc-DMSA or control mice $(n=3$ in each group) were separated under nonreducing conditions by SDS-PAGE $(16 \%)$. For protein identification, gels were silver-stained using Proteosilver Plus according to the manufacturer's instructions (SigmaAldrich) and dried, and the position of the ${ }^{99 \mathrm{~m}} \mathrm{Tc}$-labeled protein was determined by autoradiography. For immunodetection, urine samples collected from megalin/cubilin-deficient mice or controls $(n=3$ in each group) were separated by unreduced SDS-PAGE (16\%) and immunoblotted as described previously (24), using rabbit-antirat

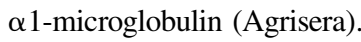

\section{Mass Spectrometry (MS)}

The in-gel digestion procedure of proteins separated by SDSPAGE was performed essentially as described before (25). The samples were digested by sequence-grade porcine trypsin, peptides were recovered by reverse-phase absorption $\left(\mathrm{C}_{18}\right.$ Stagetip; Proxeon Biosystems), and the sample was eluted directly onto the matrixassisted laser desorption/ionization (MALDI) target using $1 \mu \mathrm{L}$ of $\alpha$-cyano-4-hydroxycinnamic acid in $70 \%$ acetonitrile and $0.1 \%$ trifluoroacetic acid. Peptides were subsequently analyzed using an Autoflex Smartbeam III instrument (Bruker Daltonics GmbH) operated in both MS and MS/MS mode (LIFT). Before analyses, the instrument was calibrated by external calibration using a peptide mix containing 7 calibrants (Bruker Daltonics). On the basis of the generated mass spectra, proteins were identified using the Mascot search engine and the Swiss-Prot database as reference.

\section{Kidney Tissue Preparation and Analysis}

After being counted on the $\gamma$-counter, kidney extracts were prepared from the collected kidneys of the megalin/cubilindeficient mice injected with ${ }^{99 \mathrm{~m}} \mathrm{Tc}-\mathrm{DMSA}$ or from control mice. In brief, kidney cortices were homogenized in ice-cold $0.3 \mathrm{M}$ sucrose, $25 \mathrm{mM}$ imidazole ( $\mathrm{pH}$ 7.2), 8.5 M leupeptin, $1 \mathrm{mM}$ phenylmethylsulfonylfluoride (PMSF), and $1 \mathrm{mM}$ ethylenediaminetetraacetic acid for $30 \mathrm{~s}$ with an Ultra-Turrax T8 homogenizer (IKA-Werke) and centrifuged at 4,000 g for $15 \mathrm{~min}$ at $4{ }^{\circ} \mathrm{C}$. Cleared supernatants (10 $\mu \mathrm{g}$ of protein) were analyzed by SDS-PAGE (16\%) and visualized by immunoblotting (24), using sheep-antirat megalin (26), rabbit-antirat cubilin (27), and rabbit antiactin (A5060; Sigma-Aldrich). Band intensities were quantified using the Odyssey software (version 1.2; LI-COR Biosciences). The megalin and cubilin protein levels in the kidneys were expressed relative to actin protein levels.

\section{In Vitro Binding Assay}

${ }^{99} \mathrm{~m}$ Tc-DMSA $(0.005 \mathrm{MBq})$ was incubated for $1 \mathrm{~h}$ at $37^{\circ} \mathrm{C}$ with buffer or purified human $\alpha 1$-microglobulin (AbD Serotec) at a final concentration of $0.05 \mathrm{mg} / \mathrm{mL}$, in a total volume of $250 \mu \mathrm{L}$ diluted in phosphate-buffered saline ( $\mathrm{pH} 7.4)$. Samples $(50 \mu \mathrm{L})$ were counted with a $\gamma$-counter before and after fractionation 
on a filter (molecular weight cutoff, $30 \mathrm{kDa}$; Amicon) by centrifugation at $4,000 \mathrm{~g}$. The experiment was performed in triplicate.

\section{Immunohistochemistry}

Kidneys from megalin/cubilin-deficient or control mice $(n=3$ in each group) were fixed by retrograde perfusion with $2 \%$ paraformaldehyde, and sections were processed as reported before (20), using sheep-antirat megalin and rabbit-antirat $\alpha 1$-microglobulin. Images were obtained using a confocal laser-scanning microscope (LSM 510-META; Carl Zeiss) and processed using Zeiss Zen software (2009, Light Edition).

\section{Statistics}

Data represent mean $\pm \mathrm{SD}$. Groups were compared using a Student unpaired $t$ test, assuming equal variance. A $P$ value of less than 0.05 was considered significant.

\section{RESULTS}

\section{Renal Uptake and Urinary Excretion of ${ }^{99 m}$ Tc-DMSA}

Accumulation of ${ }^{99 \mathrm{~m}}$ Tc-DMSA uptake in the kidneys of normal control mice was evident by whole-body $\gamma$-camera scintigraphy $6 \mathrm{~h}$ after intravenous injection of ${ }^{99 \mathrm{~m} T c-}$ DMSA (Fig. 1A). In contrast, no accumulation was seen in the kidneys of megalin/cubilin-deficient mice (Fig. 1B). When quantified by $\gamma$-counting, the uptake of ${ }^{99 \mathrm{~m} T c-}$ DMSA in isolated kidneys from megalin/cubilin-deficient mice was reduced to $1.8 \% \pm 0.4 \%$ of the injected dose per $100 \mathrm{mg}$ of kidney tissue (Fig. 2A), corresponding to $11.4 \%$ of the normal uptake in controls ( $n=7$ in each group). This uptake was associated with an approximate $90 \%$ increase in the urinary excretion of ${ }^{99} \mathrm{~m}$ Tc-DMSA (Fig. 2B). Thus, whereas the total renal activity of megalin/cubilin-deficient mice was $8,882 \pm 3,264 \mathrm{cpm}$, compared with $66,656 \pm$ $9,336 \mathrm{cpm}(P<0.0001)$ in controls, the total activity of 99m Tc-DMSA extracted by the kidneys (kidney plus urine activity) was not significantly different between megalin/ cubilin-deficient mice and control mice $\left(7.9 \cdot 10^{3} \pm 1.6 \cdot 10^{3}\right.$ vs. $6.5 \cdot 10^{3} \pm 1.2 \cdot 10^{3} \mathrm{cpm} / \mathrm{g}$ mouse, $\left.P=0.07\right)$.

The approximate $90 \%$ reduction in kidney uptake of the tracer correlates with a megalin and cubilin protein knockdown efficiency of $90.8 \% \pm 8.7 \%$ and $89.8 \% \pm$ $6.1 \%$, respectively, as evaluated by immunoblotting of kidney cortex homogenates from megalin/cubilin-deficient

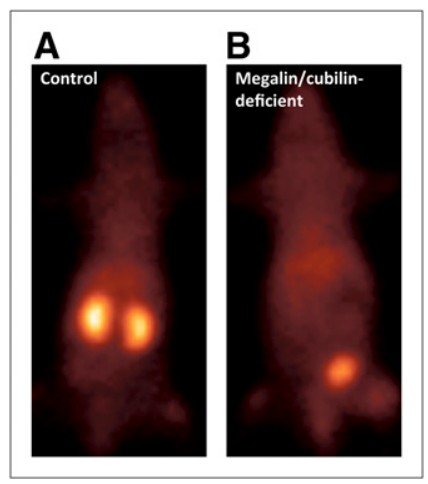

FIGURE 1. Megalin/cubilindependent renal accumulation of $99 \mathrm{~m} T \mathrm{c}-\mathrm{DMSA}$. Whole-body scintigram of mice $6 \mathrm{~h}$ after injection of ${ }^{99 m T c-D M S A ~ s h o w s ~}$ accumulation in kidneys of control mice (A) but no accumulation in kidneys of megalin/cubilindeficient mice (B). In megalin/ cubilin-deficient mice, evidence of accumulation of tracer in bladder was seen. Images shown are representative of similar analyses ( $n=3$ in each group). mice, compared with controls, which is similar to previous reports in these mice (22). The plasma level of $99 \mathrm{~m}$ TcDMSA in megalin/cubilin-deficient mice and controls was not significantly different (Fig. 2C).

\section{Urinary Excretion of 99mTc-MAG3}

No significant difference $(P=0.11)$ in the urinary excretion of ${ }^{99 \mathrm{~m}}$ Tc-MAG3 was observed between megalin/ cubilin-deficient $(n=7)$ and control mice $(n=7$, Fig. 3$)$ after $6 \mathrm{~h}$. Although we cannot rule out a potential difference in the kinetic parameters of ${ }^{99 \mathrm{~m}} \mathrm{Tc}-\mathrm{MAG} 3$ handling, the total excretion of ${ }^{99 \mathrm{~m}} \mathrm{Tc}-\mathrm{MAG} 3$ appears to be unaffected by the megalin/cubilin deficiency.

\section{Urinary Excretion of Protein-Bound ${ }^{99 m T c-D M S A}$}

The molecular weight of the ${ }^{99 \mathrm{~m}} \mathrm{Tc}$ activity in urine was determined through size fractionation by successive application of urine to centrifuge filters, thereby producing fractions corresponding to molecular weights of more than 100 , $30-100,10-30,3-10$, and less than $3 \mathrm{kDa}$. In urine from megalin/cubilin-deficient mice, $60 \%$ of the injected dose of ${ }^{99 m}$ Tc-DMSA was associated with fractions corresponding to a molecular weight of more than $10 \mathrm{kDa}$, compared with only $17 \%$ in urine from control mice (Table 1). In both controls and megalin/cubilin-deficient mice, 2\%-3\% was bound to small peptides $(3-10 \mathrm{kDa})$, and $19 \%-20 \%$ was excreted as small molecules, including amino acid-bound and free ${ }^{99 \mathrm{~m}}$ Tc-DMSA. Thus, the increased ${ }^{99 \mathrm{~m}}$ Tc-DMSA activity in the urine of megalin/cubilin-deficient mice reflects a 3.5-fold increase of protein-bound ${ }^{99 \mathrm{~m}} \mathrm{Tc}-\mathrm{DMSA}$ excreted in the urine.

\section{Identification of $99 \mathrm{mTc}$ TMSA Bound to $\alpha 1$-Microglobulin}

The analysis of urine samples collected from megalin/ cubilin-deficient mice by SDS-PAGE and autoradiography showed that the ${ }^{99 \mathrm{~m}} \mathrm{Tc}$ radioactivity was associated with a single band of approximately $27 \mathrm{kDa}$ (Fig. 4A). To identify the protein associated with the tracer, the collected urine samples were subjected to SDS-PAGE, and proteins were visualized by silver staining. The sample representing megalin/cubilin-deficient mice presents unique staining at the position corresponding to $27 \mathrm{kDa}$ (Fig. 4B). This band was excised, subjected to in-gel digestion using trypsin, and subsequently identified as the plasma protein $\alpha 1$-microglobulin by MALDI MS (Table 2). This finding was further corroborated by immunoblotting (Fig. 4C). The interaction between ${ }^{99 \mathrm{~m}}$ Tc-DMSA and $\alpha 1$-microglobulin was furthermore evaluated in vitro using purified $\alpha 1$-microglobulin, whereby approximately $80 \%$ of the $99 \mathrm{~m}$ Tc-DMSA activity was found bound to $\alpha 1$-microglobulin after $1 \mathrm{~h}$ of incubation. Finally, immunohistochemical staining of kidney sections from control and megalin/cubilin-deficient mice demonstrated proximal tubule uptake of $\alpha 1$-microglobulin in megalin-expressing cells only, confirming that megalin is essential for uptake of $\alpha 1$-microglobulin (Fig. 5). 
FIGURE 2. Renal uptake and urinary excretion of ${ }^{99 m T c-D M S A}$ by megalin/cubilindeficient and control mice. Renal uptake (A), urinary excretion $(B)$, and plasma levels $(C)$ of ${ }^{99 m}$ Tc-DMSA in megalin/cubilin-deficient mice are compared with controls. Columns represent mean of each group $(n=7) \pm \mathrm{SD}$. *Significantly different from control mice $(P<0.0001)$.
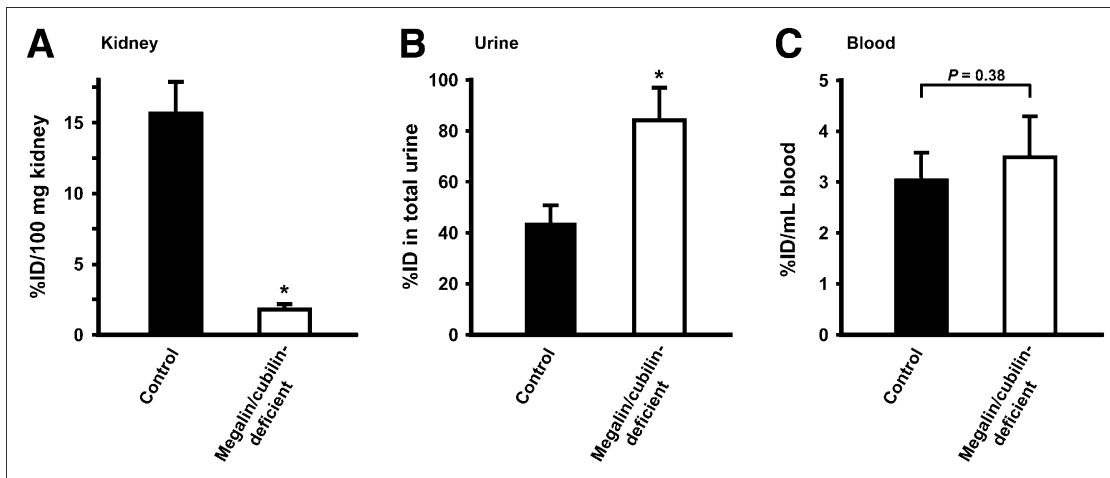

\section{DISCUSSION}

We show that in megalin/cubilin-deficient mice, the renal accumulation of ${ }^{99 \mathrm{~m}} \mathrm{Tc}-\mathrm{DMSA}$ is almost abolished and associated with a corresponding increase in urinary excretion of the tracer. The increased ${ }^{99 \mathrm{~m}} \mathrm{Tc}-\mathrm{DMSA}$ activity in the urine is found to be associated with high-molecular-weight fractions, suggesting protein binding. MS and in vitro binding studies identified $\alpha 1$-microglobulin as the ${ }^{99 m} \mathrm{Tc}-$ DMSA binding protein present in urine. $\alpha 1$-microglobulin is a $27-\mathrm{kDa}$ plasma protein filtered in the glomeruli and an established ligand for both megalin and cubilin $(21,24)$. This is confirmed by immunohistochemistry showing uptake of $\alpha 1$-microglobulin in megalin-expressing tubule cells only. On the basis of these observations, we proposed a new model for renal accumulation of ${ }^{99 m}$ Tc-DMSA (Fig. 6). In this model, ${ }^{99 \mathrm{~m} T c-D M S A}$ binds to $\alpha 1$-microglobulin, which is filtered as a complex in the normal renal glomeruli followed by megalin/cubilin-mediated endocytic uptake and accumulation of the tracer in the kidney proximal tubules.

An approximate $10 \%$ residual renal uptake of ${ }^{99 \mathrm{~m} T c-}$ DMSA was observed in the kidneys from megalin/cubilindeficient mice. Although an additional and minor pathway for renal uptake of ${ }^{99 \mathrm{~m} T c-D M S A}$ cannot be excluded, this corresponds to the possibility that the approximately $10 \%$ remaining megalin expression in these mice is a likely explanation for the residual uptake. This argument is also consistent with a previous study using kidney-specific megalin- deficient mice, in which a renal uptake of $35 \%-55 \%$ of ${ }^{99 \mathrm{~m}} \mathrm{Tc}-\mathrm{DMSA}$ was reported in megalin-deficient mice, compared with normal controls, although the data were not shown in the study (12). Previous analyses, however, showed that these megalin-deficient mice have a partial and variable (35\%-50\%) megalin expression in the kidneys (28), explaining this variation in ${ }^{99 \mathrm{~m}} \mathrm{Tc}-\mathrm{DMSA}$ uptake.

The renal ${ }^{99 \mathrm{~m}} \mathrm{Tc}-\mathrm{DMSA}$ uptake in megalin/cubilin-deficient mice was reduced to $1.8 \% \pm 0.4 \%$ of the total injected dose per $100 \mathrm{mg}$ of kidney tissue, whereas the uptake in control mice was $15.6 \% \pm 2.3 \%$, similar to what has been reported in rats (12). Importantly, the total activity of ${ }^{99 \mathrm{~m} T c-D M S A}\left(7.9 \cdot 10^{3} \pm 1.6 \cdot 10^{3} \mathrm{cpm} / \mathrm{g}\right)$ extracted by the kidneys (kidney plus urine activity) of megalin/cubilin-deficient mice was not significantly different from that of control mice $\left(6.5 \cdot 10^{3} \pm 1.2 \cdot 10^{3} \mathrm{cpm} / \mathrm{g}\right)(P=0.07)$, indicating similar renal extraction and filtration of ${ }^{99 \mathrm{~m}} \mathrm{Tc}-\mathrm{DMSA}$.

$\alpha 1$-microglobulin, a member of the lipocalin protein superfamily, is synthesized in the liver, freely filtered by glomeruli, and reabsorbed by renal proximal tubule cells, where it is catabolized (29). Under normal conditions, little filtered $\alpha 1$-microglobulin appears in the final excreted urine; however, urinary excretion of $\alpha 1$-microglobulin has been demonstrated previously in megalin-deficient mice (21) and $\alpha 1$-microglobulin was recently shown to be excreted in the urine of a patient with cubilin dysfunction, where additional binding experiments confirmed that both megalin and cubilin bind $\alpha 1$-microglobulin (24). An in-

TABLE 1

Ultrafiltration of Urine from Mice Injected with ${ }^{99 m}$ Tc-DMSA

\begin{tabular}{lcc}
\hline Molecular weight $(\mathrm{kDa})$ & Control & Megalin/cubilin-deficient \\
\hline$>100$ & 4 & 8 \\
$30-100$ & 9 & 43 \\
$10-30$ & 4 & 9 \\
$3-10$ & 3 & 2 \\
$<3$ & 20 & 19
\end{tabular}

Values are from mixed urines $(n=3)$ and expressed as percentage of injected dose.
FIGURE 3. Urinary excretion of 99mTc-MAG3 by megalin/ cubilin-deficient and control mice. Columns represent mean of each group $(n=7)$ $\pm \mathrm{SD}$.

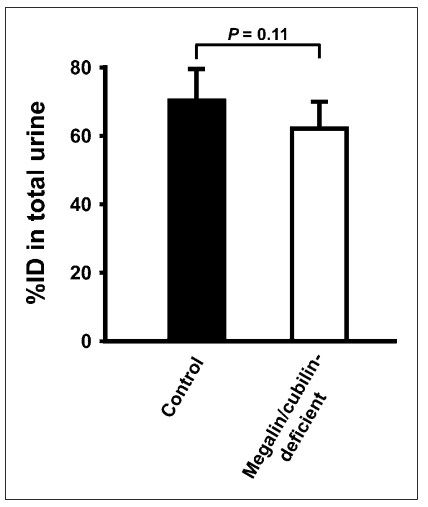

centage of injected dose. 


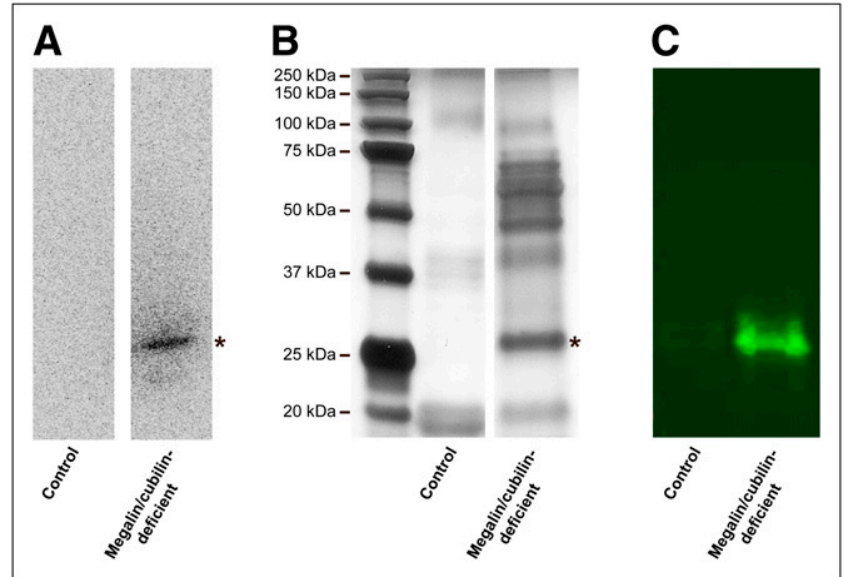

FIGURE 4. Urinary excretion of protein-bound ${ }^{99 m T c-D M S A}$ by megalin/cubilin-deficient mice. (A) SDS-PAGE separation and autoradiography of urine from megalin/cubilin-deficient mice and controls injected with 99mTc-DMSA. A single, labeled band of approximately $27 \mathrm{kDa}$ is observed in urine collected from megalin/ cubilin-deficient mice only. (B) Urine profile analysis by SDS-PAGE and silver staining of urine from megalin/cubilin-deficient mice and controls. A distinct protein band of $27 \mathrm{kDa}$ was identified in urine from megalin/cubilin-deficient mice $\left(^{*}\right)$. This band was excised and protein identified by MALDI MS as $\alpha 1$-microglobulin (Table 2). (C) Immunoblotting identifying $\alpha 1$-microglobulin as an approximate 27$\mathrm{kDa}$ band in urine from megalin/cubilin-deficient mice but not from controls. Data shown are representative of 2 (autoradiography and MALDI MS) or 3 (SDS-PAGE, silver staining, and immunoblotting) independent experiments.

crease in the urinary concentration of $\alpha 1$-microglobulin therefore indicates proximal tubule cell injury or impaired proximal tubular endocytosis and is considered a valuable marker of renal proximal tubular dysfunction (30-32). Interestingly, similar to our findings in urine from megalin/ cubilin-deficient mice, the molecular size of excreted $99 \mathrm{~m}$ Tc-DMSA in the urine of patients with idiopathic tubular proteinuria is also in the range of $24-28 \mathrm{kDa}(33)$, supporting binding to a urinary protein of this size. Our study showed no uptake of $\alpha 1$-microglobulin in megalinnegative tubular cells independent of cubilin expression. Thus, although $\alpha 1$-microglobulin may bind to both cubilin and megalin, megalin is essential for the internalization of the cubilin- $\alpha 1$-microglobulin complex, as also shown for other proteins binding to both receptors, such as albumin
(20). It has previously been shown that most $(65 \%-90 \%)$ 99m Tc-DMSA in plasma is protein-bound $(6,31,34)$, and it has been proposed that the sulfhydryls in DMSA bind to free cysteine residues. $\alpha 1$-microglobulin has a free cysteine side-chain located in a flexible loop, giving the protein reductase and dehydrogenase properties with a broad biologic substrate specificity (35). It is therefore likely that the binding of ${ }^{99 \mathrm{~m}} \mathrm{Tc}$-DMSA to $\alpha 1$-microglobulin occurs via its free cysteine residue.

On the basis of our findings, the renal uptake of ${ }^{99 \mathrm{~m}} \mathrm{Tc}-$ DMSA depends on the binding to $\alpha 1$-microglobulin, whereby it becomes a ligand for the megalin/cubilin receptors; the glomerular filtration of $\alpha 1$-microglobulin; and the activity of proximal tubule megalin/cubilin-mediated endocytosis. Under conditions for which the first 2 factors may be assumed to be constant, a ${ }^{99 \mathrm{~m}} \mathrm{Tc}-\mathrm{DMSA}$ scan will reflect the receptor-mediated endocytic activity in the proximal tubule, as is supported by several studies showing poor ${ }^{99 \mathrm{~m} T c-D M S A}$ renal uptake in patients with disturbed tubular endocytosis and subsequent low-molecular-weight proteinuria, including Dent's disease, Lowes syndrome, and Fanconi syndrome $(10,15,16)$. Reduced ${ }^{99 m}$ Tc-DMSA uptake in these patients is associated with increased bladder activity, indicating an increased urinary excretion of ${ }^{99 \mathrm{~m}} \mathrm{Tc}$-DMSA, and correlates with the degree of tubular proteinuria (10). However, quantitative estimates of megalin/ cubilin function will require further studies, including evaluation of the dynamics of ${ }^{99} \mathrm{~m}$ Tc-DMSA uptake and relating it to the glomerular filtration rate in conditions with varying degree of tubulopathy. In the case of heavy proteinuria, an altered tracer distribution could be due to the increased glomerular filtration of proteins, leading to increased urinary loss and reduced ${ }^{99 \mathrm{~m}} \mathrm{Tc}-\mathrm{DMSA}$ uptake, as reported (36). Conversely, diminished filtration would lead to low ${ }^{99 \mathrm{~m}} \mathrm{Tc}$-DMSA kidney uptake, even while tubular function is retained, as it is observed under renal artery stenosis and captopril experiments $(5,37)$. Thus, ${ }^{99 \mathrm{~m} T c-D M S A}$ renal uptake should also be cautiously interpreted in the case of alterations in glomerular filtration.

Our findings may also explain previous observations made in a mouse model of Dent's disease caused by knockout of the renal, endosome-associated chloride channel

TABLE 2

Mass Spectrometry (MS/MS) Analysis of Trypsin-Cleaved 27-kDa Band from Urine Separated by SDS-PAGE

\begin{tabular}{ccc}
\hline \multicolumn{1}{c}{ Protein } & Measured peptide mass $(\mathrm{Da})$ & Peptide sequence identified by MS/MS \\
\hline$\alpha 1$-microglobulin & $1,131.6$ & K.LYGREPQLR.D \\
& $1,354.6$ & R.GVCEEITGAYQK.T \\
& $1,510.7$ & R.RGVCEEITGAYQK.T \\
& $1,809.8$ & K.WYNLAVGSTCPWLSR.I \\
& $2,090.0$ & K.DVALNVGISENSIIFMPDR.G
\end{tabular}

${ }^{*}$ Mascot score, 393. 
FIGURE 5. Megalin/cubilin-dependent renal uptake of $\alpha 1$-microglobulin. Immunohistochemical staining is shown for megalin (green) and $\alpha 1$-microglobulin (red) in kidney cortex of control and megalin/cubilindeficient mice. In megalin/cubilin-deficient mice, a few profiles of megalin-expressing proximal tubule cells can be identified $\left(^{*}\right)$ because of mosaic expression. Merged images showed that $\alpha 1$-microglobulin cannot be identified in proximal tubular cells lacking megalin.
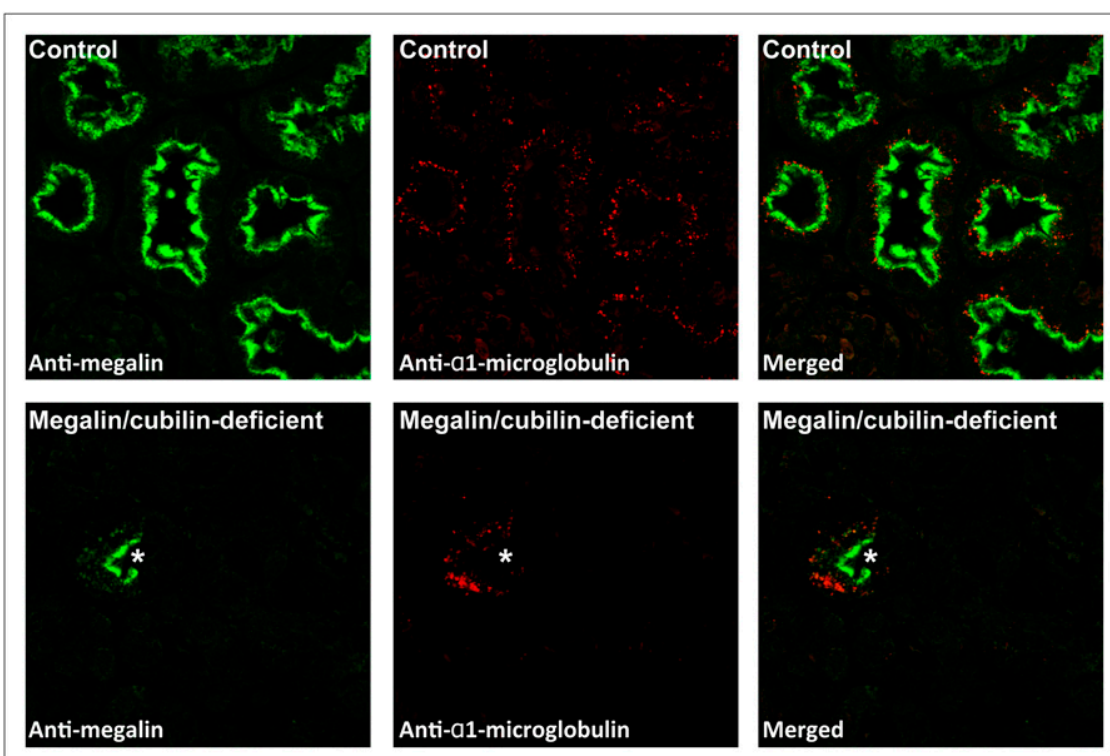

ClC-5. In Clcn5 knockout mice, impaired uptake of ${ }^{99 m} \mathrm{Tc}-$ DMSA was observed (11). The Clcn5 knockout mice are known to display disturbed megalin/cubilin-mediated endocytic activity due to impaired trafficking of the receptors (38), accompanied by an increased urinary excretion of $\alpha 1$-microglobulin (39). Thus, although it was proposed that CLC-5 affects trafficking of NaDC transporters (40), it seems likely that dysfunction of megalin/cubilinmediated endocytosis is the actual cause of impaired

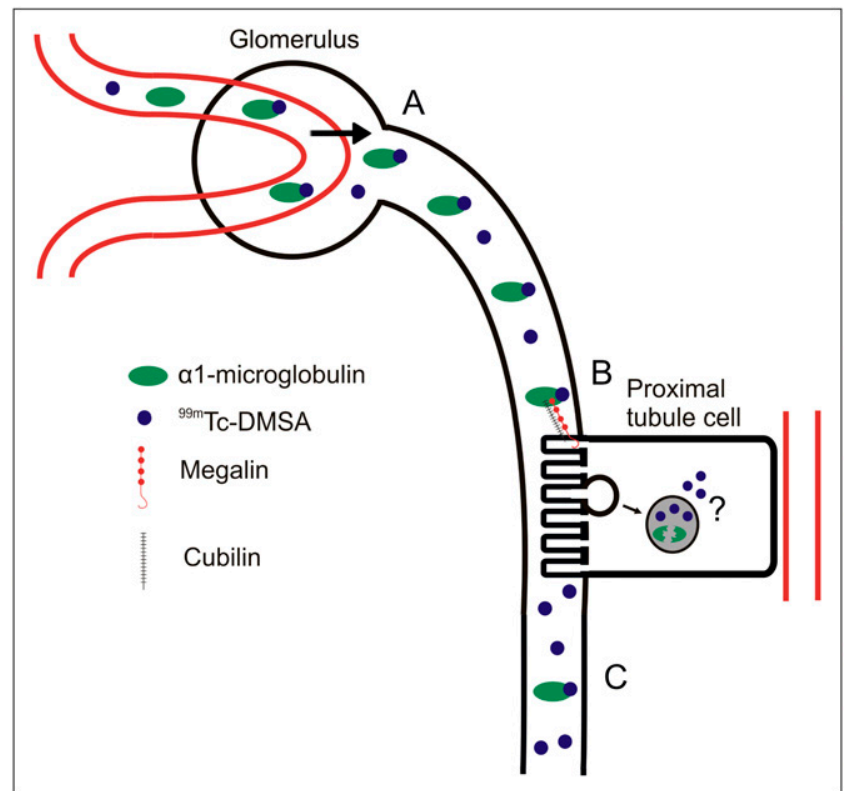

FIGURE 6. Mechanism for renal uptake of 99mTc-DMSA. (A) $\alpha 1-$ microglobulin-bound ${ }^{99 m}$ Tc-DMSA is freely filtered by glomeruli and accumulates in renal proximal tubules by endocytosis mediated by multiligand-binding megalin/cubilin receptors (B). (C) Free ${ }^{99 m T c-}$ DMSA and trace amounts of $\alpha 1$-microglobulin-bound 99mTc-DMSA are excreted in urine. Consequently, megalin/cubilin dysfunction leads to abolishment of renal uptake and increased urinary excretion of $\alpha 1$-microglobulin-bound ${ }^{99 m T c-D M S A . ~}$
${ }^{99 m}$ Tc-DMSA uptake in these mice. Interestingly, similar to what our data indicate in megalin/cubilin-deficient mice, the renal uptake of ${ }^{99 \mathrm{~m}} \mathrm{Tc}-\mathrm{MAG} 3$ was normal in Clcn5 knockout mice (11), suggesting that the basolateral uptake mediated by an organic anion transporter (41), and its excretion by proximal tubular cells, is not disturbed by defective endocytosis.

\section{CONCLUSION}

We have shown that megalin/cubilin receptor-mediated endocytosis is essential for normal renal accumulation of the ${ }^{99 \mathrm{~m}}$ Tc-DMSA tracer. Renal uptake depends on the binding of ${ }^{99 \mathrm{~m}} \mathrm{Tc}-\mathrm{DMSA}$ to the plasma protein $\alpha 1$-microglobulin, followed by glomerular filtration and megalin/ cubilin-mediated endocytosis by proximal tubular cells. Thus, the ${ }^{99 \mathrm{~m}}$ Tc-DMSA renography is a potential method for the evaluation of proximal tubule endocytic function in patients.

\section{DISCLOSURE}

The costs of publication of this article were defrayed in part by the payment of page charges. Therefore, and solely to indicate this fact, this article is hereby marked "advertisement" in accordance with 18 USC section 1734.

\section{ACKNOWLEDGMENTS}

The work was supported by the Lundbeck Foundation, the Danish Medical Research Council, Novo Nordisk Foundation, the European Commission EUNEFRON (FP7, GA\#201590), The Danish Kidney Association, and The Aase and Ejnar Danielsens Foundation. No other potential conflict of interest relevant to this article was reported. Hanne Sidelmann, Inger Blenker Kristoffersen, Pia Kamuk Nielsen, Helle Salling Gittins, and Lene E. Nielsen are gratefully acknowledged for excellent technical assistance. 


\section{REFERENCES}

1. Durand E, Prigent A. The basics of renal imaging and function studies. $Q \mathrm{~J} \mathrm{Nucl}$ Med. 2002;46:249-267.

2. Willis KW, Martinez DA, Hedley-Whyte ET, Davis MA, Judy PF, Treves S. Renal localization of ${ }^{99 \mathrm{~m}} \mathrm{Tc}$-stannous glucophetonate and ${ }^{99 \mathrm{~m}} \mathrm{Tc}$-stannous dimercaptosuccinate in the rat by frozen section autoradiography: the efficiency and resolution of technetium-99m. Radiat Res. 1977;69:475-488.

3. van Luijk WH, Ensing GJ, Meijer S, Donker AJ, Piers DA. Is the relative ${ }^{99 m}$ TcDMSA clearance a useful marker of proximal tubular dysfunction? Eur J Nucl Med. 1984;9:439-442.

4. Provoost AP, Van Aken M. Renal handling of technetium-99m DMSA in rats with proximal tubular dysfunction. J Nucl Med. 1985;26:1063-1067.

5. Peters AM, Jones DH, Evans K, Gordon I. Two routes for ${ }^{99 \mathrm{~m}} \mathrm{Tc}-\mathrm{DMSA}$ uptake into the renal cortical tubular cell. Eur J Nucl Med. 1988;14:555-561.

6. de Lange MJ, Piers DA, Kosterink JG, et al. Renal handling of technetium- $99 \mathrm{~m}$ DMSA: evidence for glomerular filtration and peritubular uptake. J Nucl Med. 1989;30:1219-1223.

7. de Lange MJ, Kosterink JG, Piers DA, van Luijk WH, Meijer S. Comments on: "Two routes for renal ${ }^{99 m}$ Tc-DMSA uptake into the renal cortical tubular cell." Eur J Nucl Med. 1989;15:633.

8. Kamper AL, Thomsen HS, Nielsen SL, Strandgaard S. Renal uptake of dimercaptosuccinic acid and glomerular filtration rate in chronic nephropathy at angiotensin converting enzyme inhibition. Eur J Nucl Med. 1990;16:85-88.

9. Müller-Suur R, Gutsche HU. Tubular reabsorption of technetium-99m-DMSA. J Nucl Med. 1995;36:1654-1658.

10. Lee BH, Lee SH, Choi HJ, et al. Decreased renal uptake of $(99 \mathrm{~m}) \mathrm{Tc}-\mathrm{DMSA}$ in patients with tubular proteinuria. Pediatr Nephrol. 2009;24:2211-2216.

11. Jouret F, Walrand S, Parreira KS, et al. Single photon emission-computed tomography (SPECT) for functional investigation of the proximal tubule in conscious mice. Am J Physiol Renal Physiol. 2010;298:F454-F460.

12. Melis M, de Swart J, de Visser M, et al. Dynamic and static small-animal SPECT in rats for monitoring renal function after ${ }^{177} \mathrm{Lu}$-labeled Tyr3-octreotate radionuclide therapy. J Nucl Med. 2010;51:1962-1968.

13. Burckhardt BC, Drinkuth B, Menzel C, et al. The renal $\mathrm{Na}(+)$-dependent dicarboxylate transporter, NaDC-3, translocates dimethyl- and disulfhydryl-compounds and contributes to renal heavy metal detoxification. J Am Soc Nephrol. 2002;13:2628-2638.

14. van Luÿk WH, Ensing GJ, Piers DA. Low renal uptake of ${ }^{99 m}$ Tc-DMSA in patients with proximal tubular dysfunction. Eur J Nucl Med. 1983;8:404-405.

15. Kim SE, Cho JT, Lee DS, et al. Poor renal uptake of technetium-99m-DMSA and technetium-99m-MDP in a patient with Fanconi syndrome and near normal glomerular filtration rate. J Korean Med Sci. 1994;9:29-34.

16. Timmis A, Jones C, Paize F. An unusual DMSA scan: answer. Pediatr Nephrol. 2012;27:225-227.

17. Christensen EI, Birn H. Megalin and cubilin: synergistic endocytic receptors in renal proximal tubule. Am J Physiol Renal Physiol. 2001;280:F562-F573.

18. Christensen EI, Birn H. Megalin and cubilin: multifunctional endocytic receptors. Nat Rev Mol Cell Biol. 2002;3:256-266.

19. Birn H, Fyfe JC, Jacobsen C, et al. Cubilin is an albumin binding protein important for renal tubular albumin reabsorption. J Clin Invest. 2000;105: 1353-1361.

20. Amsellem S, Gburek J, Hamard G, et al. Cubilin is essential for albumin reabsorption in the renal proximal tubule. J Am Soc Nephrol. 2010;21:1859-1867.
21. Leheste JR, Rolinski B, Vorum H, et al. Megalin knockout mice as an animal model of low molecular weight proteinuria. Am J Pathol. 1999;155:1361-1370.

22. Weyer K, Storm T, Shan J, et al. Mouse model of proximal tubule endocytic dysfunction. Nephrol Dial Transplant. 2011;26:3446-3451.

23. Saito A, Sato H, Iino N, Takeda T. Molecular mechanisms of receptor-mediated endocytosis in the renal proximal tubular epithelium. J Biomed Biotechnol. 2010;2010:403272.

24. Storm T, Emma F, Verroust PJ, Hertz JM, Nielsen R, Christensen EI. A patient with cubilin deficiency. $N$ Engl J Med. 2011;364:89-91.

25. Shevchenko A, Tomas H, Havlis J, Olsen JV, Mann M. In-gel digestion for mass spectrometric characterization of proteins and proteomes. Nat Protoc. 2006;1: 2856-2860.

26. Moestrup SK, Nielsen S, Andreasen P, et al. Epithelial glycoprotein-330 mediates endocytosis of plasminogen activator-plasminogen activator inhibitor type-1 complexes. J Biol Chem. 1993;268:16564-16570.

27. Le Panse S, Galceran M, Pontillon F, et al. Immunofunctional properties of a yolk sac epithelial cell line expressing two proteins gp280 and gp330 of the intermicrovillar area of proximal tubule cells: inhibition of endocytosis by the specific antibodies. Eur J Cell Biol. 1995;67:120-129.

28. Vegt E, Melis M, Eek A, et al. Renal uptake of different radiolabelled peptides is mediated by megalin: SPECT and biodistribution studies in megalin-deficient mice. Eur J Nucl Med Mol Imaging. 2011;38:623-632.

29. Strober W, Waldmann TA. The role of the kidney in the metabolism of plasma proteins. Nephron. 1974;13:35-66.

30. Weber MH, Verwiebe R. Alpha 1-microglobulin (protein HC): features of a promising indicator of proximal tubular dysfunction. Eur J Clin Chem Clin Biochem. 1992;30:683-691.

31. Penders J, Delanghe JR. Alpha 1-microglobulin: clinical laboratory aspects and applications. Clin Chim Acta. 2004;346:107-118.

32. Guder WG, Hofmann W. Clinical role of urinary low molecular weight proteins: their diagnostic and prognostic implications. Scand J Clin Lab Invest Suppl. 2008;241:95-98.

33. Suzuki S, Suzuki J, Kume K, et al. Poor renal accumulation of ${ }^{99 m}$ Tc-DMSA in idiopathic tubular proteinuria. Nephron. 1999;81:49-54.

34. Freitas RS, Gutfilen B, da Fonseca LM, Bernardo-Filho M. Evaluation of 99mtechnetium-radiopharmaceutical binding to blood elements using different trichloroacetic acid concentrations. Yale J Biol Med. 1996;69:483-488.

35. Akerström B, Logdberg L, Berggard T, Osmark P, Lindqvist A. alpha(1)-Microglobulin: a yellow-brown lipocalin. Biochim Biophys Acta. 2000;1482:172-184.

36. Evans K, Lythgoe MF, Anderson PJ, Smith T, Gordon I. Biokinetic behavior of technetium-99m-DMSA in children. J Nucl Med. 1996;37:1331-1335.

37. Hovinga TK, Beukhof JR, van Luyk WH, Piers DA, Donker AJ. Reversible diminished renal ${ }^{99 \mathrm{~m}} \mathrm{Tc}$-DMSA uptake during converting-enzyme inhibition in a patient with renal artery stenosis. Eur J Nucl Med. 1984;9:144-146.

38. Christensen EI, Devuyst O, Dom G, et al. Loss of chloride channel ClC-5 impairs endocytosis by defective trafficking of megalin and cubilin in kidney proximal tubules. Proc Natl Acad Sci USA. 2003;100:8472-8477.

39. Norden AG, Scheinman SJ, Deschodt-Lanckman MM, et al. Tubular proteinuria defined by a study of Dent's (CLCN5 mutation) and other tubular diseases. Kidney Int. 2000;57:240-249.

40. Mo L, Wills NK. ClC-5 chloride channel alters expression of the epithelial sodium channel (ENaC). J Membr Biol. 2004;202:21-37.

41. Shikano N, Kanai Y, Kawai K, Ishikawa N, Endou H. Transport of ${ }^{99 \mathrm{~m}}$ Tc-MAG3 via rat renal organic anion transporter 1. J Nucl Med. 2004;45:80-85. 